\title{
シンポジウム(9) 耳鼻咽喉科領域の栄養管理と腸内細菌
}

\author{
司会のことば \\ 岡本 美孝 \\ 千葉労災病院 \\ 保富 宗城 \\ 和歌山県立医科大学 耳鼻咽喉科・頭頸部外科
}

近年の高齢化社会への変化と医療水準の高度化に伴い、より質の高い医療の提供が望まれている。栄養管理は、医療 安全および感染制御とともに、医療の基盤となる重要な課題である。

耳鼻咽喉科・頭頸部外科領域は、気道とともに消化管の門戸に位置し、摂食・嚥下に深く関与する。とりわけ、頭頸 部癌の診療においては、摂食・嚥下機能の障害や進行性の栄養不良状態を伴う場合が多く見られ、栄養管理は重要な課 題となる。一般に、外科手術は頭頸部癌治療において重要な位置を占めるが、手術侵襲は炎症反応の立進や細胞性免疫 の低下などの生体反応を引き起こす要因となる。炎症反応は異化を立進させ、さらなる低栄養を起こす要因となり、縫 合不全や術後感染などの合併症を起こす要因となる。一方、術後合併症は入院期間の延長だけでなく長期予後を悪化さ せることが知られている。このようなことから、栄養管理は周術期合併症の予防において重要であり、有効な栄養治療 や栄養管理を行うことは、癌治療において治療効果を高める有効な武器となる。耳鼻咽喉科領域の治療に際しても、栄 養管理に十分注意を払うことが必要である。

栄養療法の第一選択は、腸を使う栄養管理、すなわち、経口栄養と経腸栄養であることが広く知られている。一方、 近年栄養管理において腸内細菌叢の持つ役割が解明されてきている。手術に伴う絶食により腸内環境が変化することで 腸内細菌叢が乱れ（dysbiosis）、バクテリアルトランスロケーションが起こり、感染性合併症の発生につながる可能性 が示唆されている。経腸栄養剤のみでなく、プロバイオティクスあるいはプレバイオテイクスの投与、さらには両者を 併用したシンバイオティクスの投与により周術期に腸内環境を維持することの重要性が注目されている。

本シンポジウムでは、「耳鼻咽喉科領域の栄養管理と腸内細菌」について 4 人のエキスパートの先生のご講演をいた だく。

滋賀医科大学医学部看護学科基礎看護学 佐々木雅也先生には、栄養管理の最新の知見について、とりわけ、腸内環 境を考慮した栄養療法の実践についてプレバイオティクスとプロバイオティクスの活用の観点も含めてご講演いただ く。

宮城県立がんセンター頭頸部外科 今井隆之先生には、頭頸部悪性腫瘍切除・遊離組織移植術における周術期栄養管 理について、宮城がんセンターにて行われている頭頸部癌手術における先駆的な栄養管理の実践についてご講演をいた だく。

京都大学耳鼻咽喉科・頭頸部外科 末廣 篤先生には、頭頸部癌患者の栄養管理について、京都大学で取り組まれて いる NST(Nutrition Support Team) に讌下（Swallow）を加えたNSST活動についてご紹介いただとともに頭頸部癌 治療における栄養管理の基本と実践についてご講演いただく。

福井大学耳鼻咽喉科・頭頸部外科 藤枝重治先生には、鼻副鼻腔疾患における食生活による短鎖脂肪酸と腸内細菌叢 の関連に基づく病態の解明について、腸内細菌叢による宿主免疫学応答の恒常性維持について、これまで取り組まれて きた細菌叢研究の知見を講演いただく。

いずれの先生も、外科治療における栄養管理を習熟した方であり、細菌叢研究のエキスパートである。栄養と細菌 叢病態に関する最新の理論と実践について興味ふかいお話いただけることが楽しみである。

本シンポジウムが、耳鼻咽喉科・頭頸部外科の多くの先生の助けとなり、栄養管理のさらなる認識につながり、診療 に活用されることになれば幸いである。 
腸内環境を考慮した栄養療法の実践

一プレバイオティクスとプロバイオティクスの活用一

佐々木雅也

滋賀医科大学 医学部 看護学科基礎看護学 (生化・栄養) ・同附属病院 栄養治療部

食事の摂取は最高の栄養法であり、これに勝る栄養法はない。しかしながら、経口拱取が不可能な場合や経口摂取だ けでは必要な栄養量を充足しない場合には、静脈栄養や経腸栄養の適応となる。中でも、経腸栄養は静脈栄養に比べて 生理的で、腸粘膜の萎縮を防止し、腸粘膜免疫系の機能も維持する優れた栄養法である。

しかしながら、通常の食事と異なるような栄養法では腸内環境もまた変化する。本来、個々の腸内細菌叢は出生時か ら幼少期の環境によって決定され、健康であれば生涯にわたって大きく変化しないとされているが、栄養法の違いは腸 内細菌叢を変化させる要因となる。すなわち、腸内細菌叢の乱れ（dysbiosis）を生じるのである。特に、静脈栄養で絶

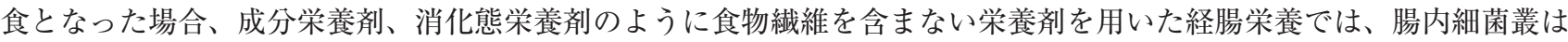
大きく変化する。このような腸内環境の変化は、経腸栄養における下痢などの消化器系合併症の要因ともなる。さらに 近年、プロトンポンプインヒビター（PPI）による dysbiosis も注目されている。したがって、臨床の現場に抒いて は、たとえClostrioides difficile の CD トキシンが陰性であっても、特別な栄養法を施行している場合、さらにPPI いている場合には、常に dysbiosis を生じていると考えるべきである。

このような dysbiosis の是正には、プレバイオティクスやプロバイオティクスの活用が効果的である。プレバイオテ イクスとしては、グアーガムなどの水溶性食物繊維の使用は、急性期においても慢性期においても、下㾥対策として有 用である。一方、プロバイオティクスとしての乳酸菌、ビフィズス菌の効果はよく知られているが、近年、酪酸菌が注 目されている。短鎖脂肪酸の中でも、酪酸は大腸粘膜のエネルギー源となるほか、プレバイオティクス効果や腸粘膜免 疫系への作用なども報告されている。さらに、プレバイオティクスとプロバイオティクスの併用、すなわちシンバイオ ティクスはより有用性が高いと考えられる。

本邦に扔いては、食物繊維の粘度や保水性を活用した半固形状流動食、あるいは $\mathrm{pH}$ による物性の違いを応用した粘 度可変型流動食も使用可能である。これらは、より生理的な胃排出、消化管運動を促し、胃食道逆流や便通異常の予 防、さらには血糖コントロールにも有用性が高いことが確認されている。

今回、臨床栄養にかかわる立場から、栄養療法における腸内環境の変化、プレバイオティクスやプロバイオティクス の有用性、さらには半固形状流動食や粘度可変型流動食の有用性について概説する。本講演が耳鼻咽喉科領域に掞ける 栄養管理の一助になれば幸いである。 
頭頸部悪性腫瘍切除・遊離組織移植術における周術期栄養管理

今井 隆之

宮城県立がんセンター 頭頸部外科

頭頸部癌患者では癌による代謝異常のみならず、飲酒や喫煙などの喏好暦や、摂食・嚥下の通路にできる部位的特殊 性から、治療前に既に栄養障害を来している症例が多い。低栄養状態とそれに伴う免疫能の低下は治療後合併症発生の 重大なリスク因子であり、当科で頭頸部悪性腫瘍切除・遊離組織移植術を施行した患者188例を対象とした解析におい て、低栄養と免疫能低下の指標となる Prognostic Nutritional Index(PNI) 40以下は術後合併症、在院日数の延長の両者 における有意なリスク因子であることが分かり（Imai T. Jpn J Clin Oncol 2020）、術前の栄養管理の重要性を再認識し ている。

頭頸部悪性腫瘍切除・遊離組織移植術は長時間の手術となり、術野も複数個所に及ぶことから患者にとって非常に侵 襲の大きな治療である。手術侵襲を低減するための試みとしてさまざまなエビデンスに基づく周術期管理方法をパッケ ージ化した Enhanced Recovery After Surgery(ERAS) プロトコルが各種癌の外科領域で浸透しつつあるが、頭頸部領 域における ERAS の実践報告はまだ少ない。筆者の所属する宮城県立がんセンターでは、2016年 9 月以降、頭頸部悪性 腫瘍切除・遊離組織移植術の周術期に ERAS プロトコルによる管理を導入している（Imai T. Acta Otolaryngol 2018, Imai T. Surg Oncol 2020)。ERAS の各種プロトコル内における構成要素として、「栄養管理」は非常に重要な位置を占 めており、プロトコルの土台、基板となるものである。

当科で運用している ERAS プロトコルでは (1) 執刀 3 時間前までの術前経口補水・糖質摂取として $12.5 \%$ 糖質含有飲 料水 $400 \mathrm{ml}$ の摂取を行っている。また、(2)アルギニン、 $\omega-3$ 脂肪酸、核酸配合栄養剤による術前免疫栄養を行ってい る。先述の PNI の研究結果より、術前の栄養状態、免疫能の向上を目指している。また、(3) 遊離空腸移植症例なども 含め、執刀翌日からの術後早期経腸栄養を行っている。いずれの介入も導入、実現のための工夫が必要であり、以下に 当科に㧍ける工夫を述べる。

頭頸部悪性腫瘍切除・遊離組織移植術の手術予定患者は管理栄養士による外来術前栄養指導を受ける。上記 3 項目を 含め、パンフレットを用い、入念に説明が行われる。(1) (2) 摂取されなければ意味がない。(1)(2)摂取量、摂取カロリ 一を計算する術前摂取量確認のための患者・医療従事者相互記入形式のチェックリストを導入している。(2)に関しては コスト面から導入が進まない施設も多いと聞く。栄養補助食品の提供の増加は食材量費の圧迫により給食の質を低下さ せる懸念があるためと考える。当科では術前免疫栄養剤と経口補水液は術前栄養指導後に売店で自己購入をしていただ いている。必要性を理解いただくための説明と、摂取量の確認の作業が重要と考える。

術翌日からの早期経腸栄養を実現するために、腸管蠕動運動促進薬の投与を行っている。早期離床、術前絶飲食期間 の短縮も胃・腸管運動の早期回復のためには重要である。さらに術後悪心・嘔吐の軽減やオピオイド必要量の減少効果 を目的に、執刀前に単回のステロイドホルモン投与を行っている。多剤による疼痛管理も同様にオピオイド減量に寄与 すると思われ、早期経腸栄養開始のためには重要と考える。術後早期に開始する経腸栄養剤は NPC/N 比74と非常に夕 ンパク質含有量の多い栄養荗を用いている。術直後は内因性エネルギー供給を考慮した permissing underfeeding が良 いと考える。 
頭頸部癌患者の栄養管理

末廣篤

京都大学 耳鼻咽喉科・頭頸部外科

頭頸部癌患者は、食物の通過経路の入口にあたる領域に病変があるため、早期より経口撖取が制限されていることが 多い。例えば、しばしば外来で遭遇する、『 3 カ月前からごはんが通らなくて、プリンとゼリーばっかりです。体重は 5 キロ滅りました…‥というような患者は、European palliative care research collaborative の悪液質のステージ分類 にしたがうと、治療前にすでに悪液質に分類されることとなる。さらに、口腔・咽頭の形態を大きく変化させるような 外科的治療、口腔咽頭に高度の粘膜炎や唾液分泌低下を来す化学放射線療法は、栄養素の摂取をさらに低下させ、治療 の完遂を妨げることもある。よって、頭頸部癌の治療においては、癌の治療だけでなく、低栄養状態の改善と良好な栄 養状態の維持が不可欠である。そこで今回、京都大学の耳鼻咽喉科・頭頸部外科で行っている栄養管理の取り組みにつ いて報告をする。

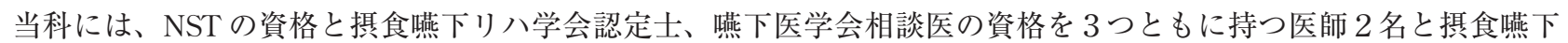
障害看護認定看護師 1 名（病棟副師長）が在籍して打り、病棟管理栄養士や薬剂師、言語療法士らとともに、頭頸部外 科だけの NSTを作り活動を行っている。治療のフェーズごとに嚥下機能に応じた栄養管理、栄養状態に応じた嚥下診 療をリアルタイムで調整することを心がけており、NST(Nutrition Support Team) に嚥下（Swallow）を加えてNSST として活動を行っている。

以下の 3 つの項目を NSST の活動の柱としている。

(1) 治療開始までの栄養状態の改善

2020年に当科を悪性腫瘍で受診した患者は104名で、SGA 栄養アセスメントを用いると、そのうち37名が栄養障害に 分類された。さらに、半減期の短い夕ンパク指標を調べると、患者の半数近く、特に進行がんではほぼ全例が著名な低 下を示していた。上部消化管癌患者では、20３0\%が低栄養であると言われており、予想通り頭頸部癌患者はさらに低 栄養患者の占める割合が多いことが分かった。

(2) 治療中の栄養状態の維持

治療中の栄養管理の目的は、低栄養に伴う副作用発現の抑制（アルブミン $3.5 \mathrm{~g} / \mathrm{dl}$ 以下では副作用が有意に増加する との報告が多い）と在院日数の短縮である。入院期間の短縮は、高齢者の認知機能低下の予防からも非常に重要だと考 えている。

典型例を 1 例呈示する。77歳の喉頭癌（T4aN2c）で、初診時のアルブミンが $3.6 \mathrm{~g} / \mathrm{dl}$ （基準値3.9 5.1）ではあった が、経口摂取を長らくできていないとのことで、半減期の短いプレアルブミンを測定すると $7.6 \mathrm{mg} / \mathrm{dl}$ (基準值 23.0 42.0） と著明に低下してしていたため、即日入院し、気管切開と経管栄養を開始した。喉頭全摘術 ・両頸部郭清術施行 後、化学放射線療法が開始するまでも栄養管理を続け、開始時にはプレアルブミン $23.2 \mathrm{mg} / \mathrm{dl}$ まで回復した。その後 も $20 \mathrm{mg} / \mathrm{dl}$ 以上をキープすることができ、口腔粘膜炎 Grade 2 で抑えることができた。化学放射線治療終了後、10日 で退院となった（図 1 )。

(3) 退院後の体重減少の予防

われわれの検討では、特に単身者で、退院に体重減少を来している患者が多かった。2020年より、退院後も管理栄養 士がひきつづき介入を行うようにしている。体重減少と癌再発には、統計学上の相関は認めなかったが、引き続き観察 を続けていきたい。

以上、当科に扔ける NSST の活動についての報告を行った。2020年より、摂食嚥下チーム加算（200点／週）が新設 され、NST 加算 (200点/週)、栄養指導料、摂食機能加算等を含めると、患者 1 人に 8 回介入すると約 4,000 点の診療 報酬となる。定期のミーティングと回診が必須ではあるが、患者の利益だけでなく診療報酬の面でも有意義な活動であ ると考える。

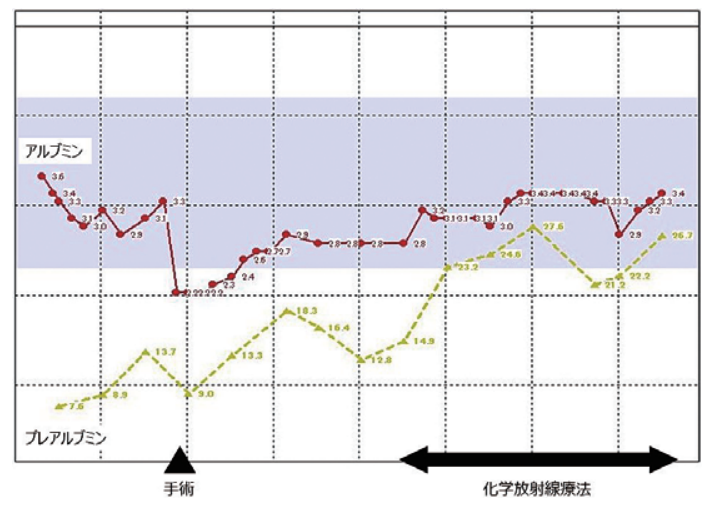

図 1 
鼻副鼻腔疾患と細菌叢

藤枝 重治、小山 佳祐、足立 直人、木戸口正典 福井大学 医学部 耳鼻咽喉科

ヒトの気道・腸管などの粘膜には100兆個以上の微生物が棲息し、微生物集合体（マイクロバイオーム）を作成して いる。これらマイクロバイオームは、粘膜細菌叢（フローラ）とも呼ばれ、主たる細菌の構成によって、さまざまな病 気の発症・状況に影響を及ぼていると言われている。アトピー性皮膚炎では、腸内細菌叢の組成は変わらずとも、特 定の菌が多くなると皮膚の状態が変化したり、アトピー性皮虐炎モデルマウスに扔いては、皮膚の細菌叢に扔いて黄色 ブドウ球菌（Staphylococcus aureus）とコリネバクテリウムが大半を占めたりすることが報告されている。

鼻副鼻腔疾患の中では、欧米の鼻茸合併慢性副鼻腔炎 (Chronic rhinosinusitis with nasal polyp：CRSwNP) におい て、鼻腔に存在する黄色ブドウ球菌が病態形成に関与していると報告されている。黄色ブドウ球菌が産生するブドウ球 菌エンテロトキシン（Staphylococcal enterotoxins, SEs）に対する SE 特異的 $\operatorname{IgE}$ を鼻茸中に証明し、SE が慢性副鼻腔 炎鼻茸形成のアレルゲン、起因物質であると考えられている。SE 自身はスーパー抗原としても働き、抗原非特異的に T 細胞を活性化させ、IL-4、IL-5、IL-13 などの Th2 サイトカインを放出させ、Th2 環境下を作ることで鼻咠形成が起 こるとしている。アレルギー性鼻炎においては、特徴的な菌の同定はなされていないが、鼻垫内に存在する菌種の減少 が問題ともされている。

今回われわれは、アレルギー性鼻炎抢よび鼻副鼻腔炎患者の鼻胿・埶・便のサンプル中細菌叢を次世代シークエン サーによって、細菌 DNA の 16SrRNA 遺伝子 V3-V4 領域を PCR 増幅し解析した。また食生活に関してもアンケート調 查を行い、アレルギー性鼻炎発症の状態、好酸球性副鼻腔炎の重症度を含めた細菌叢との関連を検討した。食生活との 関連では、発酵食品の摂取量とアレルギー性鼻炎発症との有無は有意な相関をしていた。また特有の細菌が食物繊維や オリゴ糖を発酵することにより生成する短鎖脂肪酸やそのほか類似物質の影響でさまざまな効果を誘導することも見出 した。短鎖脂肪酸は、炭素の数が 6 個以下の脂肪酸で、酢酸、プロピオン酸、酪酸、吉草酸、カプロン酸からなる。生 成された短鎖脂肪酸は粘膜腔側に存在するが、その後、上皮細胞内に取り达まれ通常エネルギー源として使用される。 しかしそれ以外にも、粘膜もしくは粘膜固有層の好中球、樹状細胞、マクロファージ、好酸球など免疫担当細胞に作用 し、さまざまな免疫バランスに影響を及ぼしていると考える。それとともに、特定の細菌の成分が、違った細菌の生体 への影響を促進したり抑制したりする可能も考えている。 